Article

\title{
Effects of Different Weeding Methods on the Biomass of Vegetation and Soil Evaporation in Eucalyptus Plantations
}

\author{
Yusong Deng ${ }^{1,2}$, Gairen Yang ${ }^{1,2, *}$, Zhifeng Xie ${ }^{1}$, Jingrui Yu ${ }^{1}$, Daihua Jiang ${ }^{3}$ and \\ Zhigang Huang 3,4 \\ 1 Forestry College of Guangxi University, No. 100 Daxue Road, Nanning 530004, China; \\ denny2018@gxu.edu.cn (Y.D.); 18473471430@163.com (Z.X.); yujingrui628@163.com (J.Y.) \\ 2 Guangxi Key Laboratory of Forest Ecology and Conservation, No. 100 Daxue Road, Nanning 530004, China \\ 3 Agricultural College of Guangxi University, No. 100 Daxue Road, Nanning 530004, China; \\ dhjiang2019@163.com (D.J.); hzg@gxu.edu.cn (Z.H.) \\ 4 Institute of Environment and Sustainable Development in Agriculture, Chinese Academy of Agricultural \\ Sciences (CAAS), Haidian District, Beijing 100081, China \\ * Correspondence: gaireny@126.com; Tel.: +86-13977152759; Fax: +86-7713271418
}

Received: 4 March 2020; Accepted: 5 April 2020; Published: 1 May 2020

\begin{abstract}
Eucalyptus is a fast-growing, short-cycle, and high-efficiency tree species that is widely planted all over the world. Weeding is a special practice for Eucalyptus plantations that aims to cultivate seedlings and reduce vegetation competition for nutrients. In this study, a typical Eucalyptus plantation was selected as the research object, and the effects of two different weeding methods on soil evaporation and plant growth were studied. The results showed that mechanical weeding could effectively remove harmful weeds at an early stage, but after 30 days of weeding, all kinds of plants gradually recovered; herbicide weeding required long-term maintenance. The herbicide had the best control effect on Microstegium vagans (Nees ex Steud.) A. Camus, Dicranopteris dichotoma (Thunb.) Bernh, and Blechnum orientale, but the effect on shrubs was not obvious. The evaporation rate of soil increased rapidly within five days after mechanical weeding. After 139-200 days of weeding, the differences in evaporation between non-weeding, herbicide weeding, and mechanical weeding was decreased. The average daily evaporation was $0.52,0.48$, and $051 \mathrm{~mm} / \mathrm{d}$ under these three practices. Meanwhile, weeding could promote Eucalyptus growth. Our results showed that weeding could significantly increase the height, diameter at breast height, and volume of Eucalyptus. One month after herbicide weeding or mechanical weeding (July), the height, DBH, and volume of Eucalyptus were significantly greater than those under non-weeding, but there was no significant difference between herbicide weeding and mechanical weeding. In addition, according to the different initial moisture contents, the evaporation rate increased with increasing initial moisture content and showed a very significant correlation.
\end{abstract}

Keywords: Eucalyptus plantation; weed; soil evaporation; vegetation biomass; forest growth

\section{Introduction}

Eucalyptus belongs to the myrtle family, which originated in Australia [1]. Eucalyptus has the advantages of high productivity, wide adaptability, and rapid economic returns, and thus has undergone rapid development driven by the market economy [2]. At present, a special Eucalyptus industrial chain has been formed, and Eucalyptus can be used as raw material to produce paper, furniture, everyday items, and medicine. In recent years, the total value of the global Eucalyptus industry has reached trillions of US dollars, of which the annual output value of China's Eucalyptus industry is 
more than RMB 550 billion [3]. In 2010, the area of Eucalyptus plantations in China reached 3.6 million ha, and Guangxi had the largest planting area of 1.647 million ha, accounting for approximately $45 \%$ of the total area of Eucalyptus plantations in China [4]. However, this increasing area has resulted in widespread focus on and controversy regarding the development of Eucalyptus forests, and the negative impact on the ecological environment has become an increasing concern. Among the areas of focus, one of the most controversial is the hydrological processes in Eucalyptus plantations, which impact the distribution of regional water resources $[5,6]$. Specifically, soil is an important storage place of water resources, and plays an important role in the process of forest hydrology.

Soil evaporation means that the water in soil escapes through the soil pores into the atmosphere in the form of water vapor, a process that is also called the invalid loss of soil water [7,8]. Evaporation is an important part of the hydrological cycle and energy transmission, as well as the link between soil, vegetation, and the atmosphere, and is also the main form of water dissipation from the earth. As an important element of the water cycle, soil evaporation is important for the efficient utilization of water resources, assessments of the ecological environment and maintenance of the water balance. Statistical data show that water entering the atmosphere through evaporation accounts for approximately $60 \%$ of the annual average precipitation [9]. Therefore, soil evaporation plays an indispensable role in the biosphere, hydrosphere, and atmosphere, and its changes have important impacts on agriculture and ecological hydrology. The influencing factors of soil evaporation are very complex and mainly include soil moisture, soil structure, soil surface characteristics, and topography [10]. Climate change will also affect the strength of soil evaporation. Previous studies have shown that soil evaporation increases logarithmically with increasing rainfall intensity $[11,12]$. However, surface cover also affects soil evaporation, and the most studied surface covers types include sand and stone cover, mulching, and litter cover [13]. In addition, it has been found that the removal of shrub grass can significantly increase the evaporation of soil water in forests [14]. At present, there are few reports about soil evaporation in forests, especially plantations, which is due to the influence of the vegetation type, surface coverage, soil moisture content, and management. In different vegetation types, the types and thicknesses of undergrowth and litter greatly influence soil evaporation. The effective methods for determining soil evaporation include the water balance method, lysimeter method, soil respiration observation instrument, and small evaporator $[15,16]$. Small evaporator [17], which is easy to carry and use in the field, has a high temporal resolution and can be applied over a large area, and the results from this device are the closest to the actual situation, making it especially suitable for forest research. However, this method is rarely reported in soil evaporation studies in forests, especially in plantations.

As fast-growing, short-cycle forests, Eucalyptus plantations require more frequent management than other plantations and more strongly interfere with forestland, thus causing water problems [18-20]. Weeding, as an important measure in Eucalyptus plantations, is an important factor that impacts the survival rate of young forests and the effectiveness of forest management [21]. In the field of agricultural production, weeding has become necessary and has been used for a long time. Weeding technology has gradually developed from manual weeding to practices such as mechanical weeding, chemical weeding, and biological weeding. However, in the field of forestry, topography and operating costs restrict the development of weeding technology. At present, conventional methods mainly include mountain refining, mechanical weeding, and chemical weeding [18,22,23]. Eucalyptus plantations are short-cycle plantations, and weeding is a common management method that lasts a long time and causes high-frequency disturbance to undergrowth vegetation. This condition is a significant difference between Eucalyptus plantations and Chinese fir, Masson pine, and other long-term plantations in terms of production and management [24]. The common plant communities of Eucalyptus plantations mainly include herbs, lianas, and ferns. Weeding can improve the light conditions under the forest, increase the resistance of young Eucalyptus forests, and eliminate the competition of weeds with Eucalyptus for nutrients [25]. Considering the protection measures of forest canopies, the weeding methods commonly used in Eucalyptus forests include mechanical weeding and chemical weeding, which are quite different in terms of operation and principle. Mechanical weeding is a physical weeding method 
that mainly refers to the use of weeding machines to remove the aboveground part of vegetation to inhibit plant growth, while the survival mode and amount of root system remaining underground vary by plant species [26,27]. Chemical weeding mainly refers to herbicide weeding, which can completely kill weeds or plants [28]. We all know that weeding can eliminate competition with weeds for soil nutrients, enhance the resistance of growing trees, and promote tree growth $[29,30]$. Previous studies have shown that weeding with herbicides can reduce the relative coverage of undergrowth grass and woody plants, which will lead to different soil evaporation intensity. [31]. In addition, Chen, Luo, Zhang, et al. found that the plant height of Hibiscus cannabinus increased after weeding treatment, and this increase was higher under chemical weeding than under mechanical weeding [32]. Lei found that different weeding methods had different effects on the growth and development of cotton. Compared with non-weeding, weeding treatments effectively increase the length, surface area, and volume of cotton roots and promoted the growth of roots, which is conducive to the high yield of cotton [33]. Tan and He studied the growth of young Chinese fir forests under different weeding methods and found that the volume of a single tree was the highest under spading and chemical weeding [34]. Furthermore, Benayas, Navarro, Espigares, et al. reported that mowing could reduce the evaporation of soil water in Quercus Linn plantations and had a significant positive synergistic effect on seedling growth [35]. However, there are few reports on soil evaporation and tree growth after frequent weeding management in Eucalyptus plantations.

In this study, mechanical weeding and herbicide weeding were used in typical Eucalyptus plantations, and non-weeding was used as a control. The objectives of this study were (i) to investigate the effect of different weeding methods on the biomass of Eucalyptus under forest; (ii) to explore the effect of different weeding methods on the soil evaporation of Eucalyptus plantations; and (iii) to evaluate the effect of different weeding methods on Eucalyptus growth. Our research aims to provide a theoretical basis for the construction of water evapotranspiration and a hydrological model of Eucalyptus plantations and provide scientific guidance for the management and sustainable development of Eucalyptus plantations.

\section{Materials and Methods}

\subsection{Site Description}

The study area is located on the Yangcun forest farm, Guangxi Zhuang Autonomous Region, China $\left(110^{\circ} 16^{\prime} 48^{\prime \prime}-110^{\circ} 20^{\prime} 40^{\prime \prime} \mathrm{E}, 23^{\circ} 09^{\prime} 23^{\prime \prime}-23^{\circ} 16^{\prime} 12^{\prime \prime} \mathrm{N}\right)$, which has a southern subtropical monsoon climate. The annual average temperature is $21.4^{\circ} \mathrm{C}$; the annual average sunshine is $1700 \mathrm{~h}$; the annual average rainfall is $1726.7 \mathrm{~mm}$, most of which is concentrated from April to September; and the average relative humidity is $80 \%$. The terrain of the study area is low-mountain and hilly areas, with an altitude of $130-410 \mathrm{~m}$ and a slope of $15^{\circ}-31^{\circ}$. The soil type is mainly lateritic soil, and the soil-forming parent material is sand shale. Most of the soil layers are $55-135 \mathrm{~cm}$ thick and acidic, with $\mathrm{pH}$ values of 4.6-4.8.

\subsection{Field Investigation and Experimental Plot Design}

In the study area, two adjacent Eucalyptus plantations with afforestation times of March 2014 (EU1) and February 2015 (EU2) were selected as experimental forests. The altitudes of EU1 and EU2 were between 152 and $233 \mathrm{~m}$, the slope direction was to the east, and the slope gradient was $24^{\circ}$. Before Eucalyptus plantations were planted, Pinus massoniana plantations were planted in both EU1 and EU2, and these were cut in December 2013 and October 2014, respectively.

After the two sample plots were cleared by fire, the hole cultivation and land preparation methods were adopted for Eucalyptus planting. The size of the planting hole was $50 \mathrm{~cm} \times 40 \mathrm{~cm} \times 50 \mathrm{~cm}$. The 'Guanglin No. 9' Eucalyptus varieties were planted using clonal tissue culture seedlings with a height of 15-20 cm. The afforestation specification of the sample plot was $2 \mathrm{~m} \times 3 \mathrm{~m}$, the afforestation density was 1650 plants $/ \mathrm{hm}^{2}$, and $400 \mathrm{~g}$ (N: P: K of 12: 8: 10) of organic compound fertilizer was applied to the hole before afforestation. EU1 was top-dressed in May 2014 and October 2014. The fertilizers 
used were urea and Eucalyptus special fertilizer (N: P: K of 18: 8: 18), and the amount applied to each plant in EU1 and EU2 was $50 \mathrm{~g}$ and $150 \mathrm{~g}$, respectively. In EU1 and EU2 forests, we set up one large sample with a projection area of $30 \mathrm{~m} \times 50 \mathrm{~m}$ and $40 \mathrm{~m} \times 50 \mathrm{~m}$, respectively, and then divided the large sample into 15 and 20 small samples, respectively, with projection area of $10 \mathrm{~m} \times 10 \mathrm{~m}$ (Figure 1).

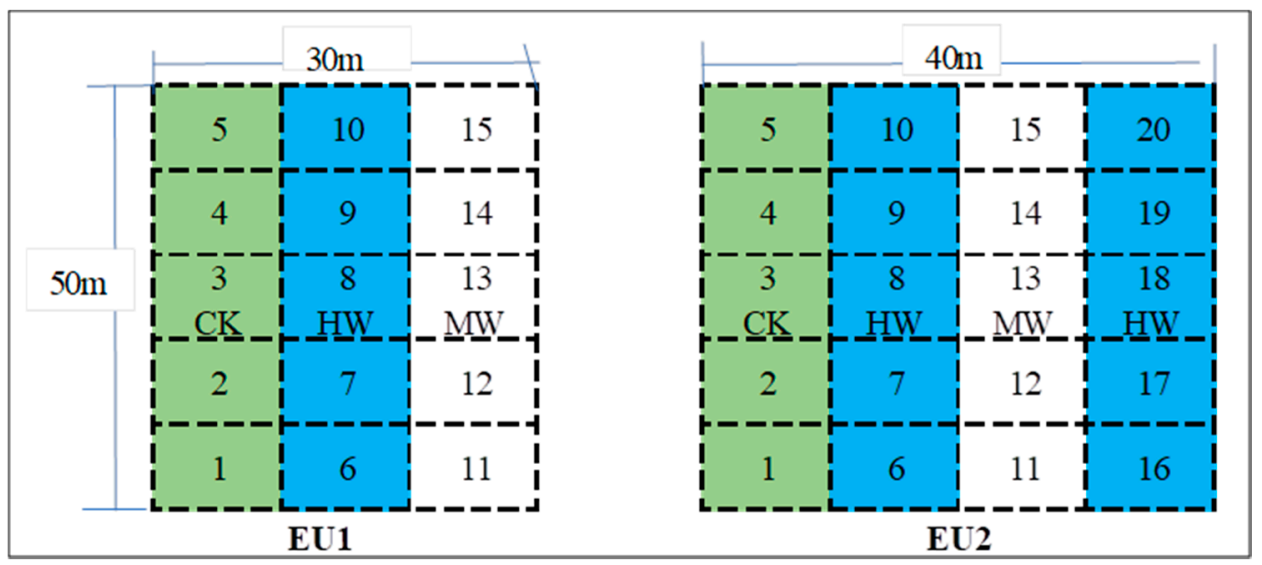

Figure 1. Schematic diagram of each processing sample plot.

As shown in Figure 1, samples 1-5 were used for the non-weeding (CK) treatment, samples 6-10 were used for the herbicide weeding (HW) treatment, samples 11-15 were used for the mechanical weeding (MW) treatment, and samples 16-20 in EU2 were used for herbicide weeding and soil evaporation observations and research on different soil moisture contents. The soil physical and chemical properties $(0-20 \mathrm{~cm})$ of EU1 and EU2 are shown in Table 1.

Table 1. Soil physical and chemical properties of the test plot.

\begin{tabular}{ccccccccccccc}
\hline $\begin{array}{c}\text { Sample } \\
\text { Plot }\end{array}$ & $\mathbf{p H}$ & $\begin{array}{c}\text { BD } \\
\left(\mathbf{g} / \mathbf{c m}^{3}\right)\end{array}$ & $\begin{array}{c}\text { CP } \\
\mathbf{( \% )}\end{array}$ & $\begin{array}{c}\text { NCP } \\
\mathbf{( \% )}\end{array}$ & $\begin{array}{c}\text { Sand } \\
\mathbf{( \% )}\end{array}$ & $\begin{array}{c}\text { Silt } \\
\mathbf{( \% )}\end{array}$ & $\begin{array}{c}\text { Clay } \\
(\mathbf{\%})\end{array}$ & $\begin{array}{c}\text { OC } \\
(\mathbf{g} / \mathbf{k g})\end{array}$ & $\begin{array}{c}\text { TN } \\
(\mathbf{g} / \mathbf{k g})\end{array}$ & $\begin{array}{c}\text { TP } \\
(\mathbf{g} / \mathbf{k g})\end{array}$ & $\begin{array}{c}\text { AN } \\
(\mathbf{m g} / \mathbf{k g})\end{array}$ & $\begin{array}{c}\text { AP } \\
(\mathbf{m g} / \mathbf{k g})\end{array}$ \\
\hline EU1 & 4.8 & 1.18 & 33.5 & 21.3 & 16.1 & 74.2 & 9.7 & 19.3 & 1.52 & 0.39 & 124.3 & 4.20 \\
EU2 & 4.7 & 1.20 & 32.7 & 22.6 & 18.3 & 73.2 & 8.5 & 17.5 & 1.50 & 0.40 & 117.7 & 4.25 \\
\hline
\end{tabular}

Note: BD: Bulk density; CP: Capillary porosity; NCP: Non capillary porosity; OC: Organic carbon; TN: Total nitrogen; TP: Total phosphorus; AN: Available nitrogen; AP: Available phosphorus.

We weeded the experimental plots of the Eucalyptus plantations on 12 June 2015. The herbicide used in the HW treatment was potassium salt of glyphosate (effective ingredient $43 \%$, produced by Syngenta) at a dosage of $2129 \mathrm{~g} / \mathrm{hm}^{2}$, and water was applied at $750 \mathrm{~kg} / \mathrm{hm}^{2}$. In the experiment, we used a knapsack sprayer to spray the surface of the grass under the forest. Meanwhile, a truck-mounted gasoline weeder was used for weeding and irrigation in the MW treatment. In addition, we used no weeding as a control (CK). On 13 June 2015, we applied fertilizer to all of the Eucalyptus in the HW, MW, and CK plots. The fertilizer used was compound fertilizer (N: P: K of 18: 8: 18), and the amount was $150 \mathrm{~g}$ per plant. The specific fertilization steps were as follows: On a $50 \mathrm{~cm}$ slope around a Eucalyptus stump, an arc ditch was dug with a depth and width of $20 \mathrm{~cm}$ and $10 \mathrm{~cm}$, respectively, and a length of $100 \mathrm{~cm}$; the fertilizer was spread evenly; and then the soil was covered.

\subsection{Measurement Indexes and Methods}

\subsubsection{Investigation of Shrub Species, Coverage, and Litter}

On 11 June 2015, the species of herbs and shrubs as well as their coverage and Eucalyptus canopy density in samples $1,2,7,8,14$, and 15 were investigated. At the diagonal intersection of the above sample plots, a $2 \mathrm{~m} \times 2 \mathrm{~m}$ survey quadrat was set, and the projection coverage of herbs, shrubs, and shrub communities was estimated visually. The canopy density of Eucalyptus was measured 
by an LAI-2200C canopy analyzer (produced by LI-COR of the United States) and calculated by FV-2200 software. Table 2 shows the results of the plant coverage and litter standing quantity of the experimental plot.

Table 2. Plant coverage and litter stock of experimental forest.

\begin{tabular}{cccccc}
\hline Sample Plot & CH (\%) & CS (\%) & CC (\%) & CE & TL (kg/hm $\mathbf{h m}^{\mathbf{2}}$ \\
\hline EU1 & 15.6 & 7.5 & 17.4 & 0.40 & 1890 \\
EU2 & 20.3 & 9.1 & 23.1 & 0.21 & 105
\end{tabular}

Note: $\mathrm{CH}$ : Total coverage of herbs; CS: Total coverage of shrub; CC: Total coverage of community; CE: Canopy density of Eucalyptus; TL: Total litter.

\subsubsection{Evaluation of the Weeding Effect}

On the 10th, 30th, 60th, and 100th days after weeding, a $2 \mathrm{~m} \times 2 \mathrm{~m}$ shrub and grass investigation quadrat was randomly set on the diagonal of each quadrat to investigate the single species coverage and total community coverage of fresh plants. Then, the fresh plants were harvested, classified, and weighed, and $200 \mathrm{~g}$ of samples (if less than $200 \mathrm{~g}$, all of them were taken) were taken back to the laboratory. The moisture content was determined by drying at $80^{\circ} \mathrm{C}$ to a constant weight. The control effect is expressed by the rate of plant decline, and the specific calculation is as follows:

$$
E=\left(\frac{\sum_{\ddot{i=1}}^{n} W_{c k i}-\sum_{\ddot{i}=1}^{m} W_{h i / m i}}{\sum_{\ddot{i}=1}^{n} W_{c k i}}\right) \times 100
$$

where $E$ is the rate of plant decline (\%); $\mathrm{n}$ and $\mathrm{m}$ are the number of plant species under control and weeding, respectively; $W_{c k i}$ is the $i$ th plant biomass (g) without weeding; and $W_{h i / m i}$ is the $i$ th plant biomass $(\mathrm{g})$ under herbicide weeding or mechanical weeding.

\subsubsection{Evaluation of Tree Growth}

On 10 and 11 June 2015, the growth of Eucalyptus in each sample plot was measured. The height of Eucalyptus was measured by a height measuring pole, and the diameter at breast height was measured by a DBH ruler. According to the average height and DBH of each plot, a standard tree was selected as a fixed sample tree for the growth survey. Every 30 days after the start of the weeding experiment, the height and DBH of the fixed sample trees were measured. There were five trees in each treatment. The volume of a single Eucalyptus tree was calculated by the improved formula of the binary growth model [36]:

$$
V=c_{0} \times D^{\left[c_{1}-c_{2}(D+H)\right.} \times H^{\left[c_{3}+c_{4}(D+H)\right]}
$$

where $V$ is the volume of Eucalyptus $\left(\mathrm{m}^{3}\right), D$ is the DBH $(\mathrm{cm}), H$ is the height $(\mathrm{m}) ; c_{0}=1.09154 \times 10^{-4}$; $c_{1}=1.87892 ; c_{2}=5.69186 \times 10^{-3} ; c_{3}=0.652598 ;$ and $c_{4}=7.84754 \times 10^{-3}$.

\subsubsection{Soil Evaporation Observation Method}

We used the observation method of Figuerola, Rousseaux, and Searles to determine soil evaporation [37].

From 13 June 2015 to 31 December 2015, soil evaporation observations were carried out by using a small evaporator on rainy days in each month, with a total of 69 days, and the number of observation days in each month was 8-11. The evaporator consisted of a stainless steel tube with an inner diameter of $111 \mathrm{~mm}$, a height of $160 \mathrm{~mm}$, and a thickness of $1 \mathrm{~mm}$; a heat-resistant rubber grommet; and a stainless steel base plate with a thickness of $1 \mathrm{~mm}$ (Figure 2). In each plot, we first randomly selected a place far away from the harvested shrub grass used to investigate the biomass, manually removed the litter on the soil surface, and then slowly pressed the stainless steel pipe into the soil to a depth of $14 \mathrm{~cm}$. Second, we used a small shovel to carefully excavate the surrounding soil to the bottom of the 
steel pipe, cut the soil column with a small steel knife, and removed the stainless steel pipe and the soil column. After the soil column was removed, the lower section of the soil column was flattened to the lower section of the steel pipe with a knife, and the bottom plate was installed. Finally, a white plastic bag covered the tube, and the weight and time were recorded with an electronic balance with an accuracy of $0.1 \mathrm{~g}$. In addition, we placed the stainless steel pipe soil column and plastic bag into another cylindrical soil hole with the same size and depth as the stainless steel pipe that was dug in advance and then spread litter on the soil column, and the amount and distribution of the litter cover was as consistent with the original situation as possible. One or two days later, we removed the stainless steel pipe and soil column and removed the litter, weighed it with an electronic balance, and recorded the weight and time. According to the speed of water evaporation, the soil column was weighed every 1 or 2 days and replaced every 2 to 4 days. Weighing and soil replacement were conducted at 17:00-17:50.

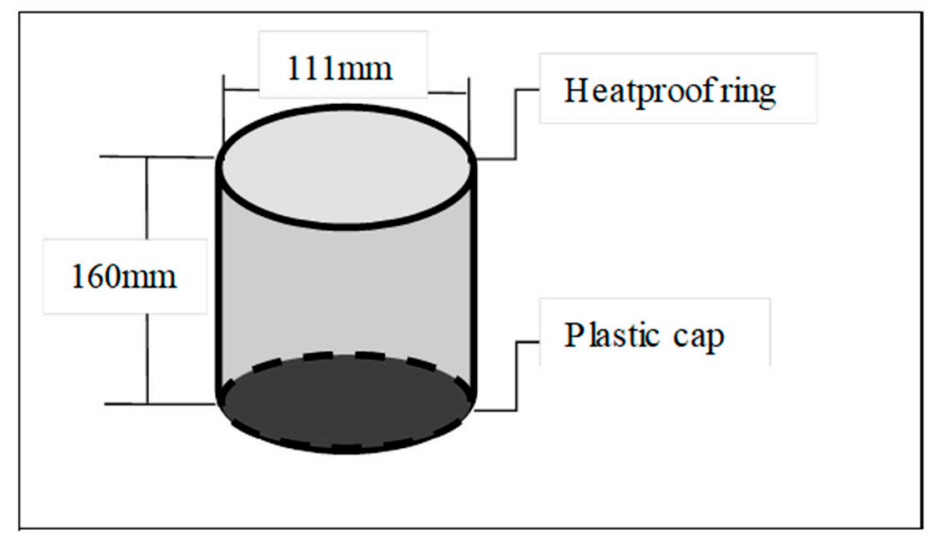

Figure 2. Structure of soil evaporator, including shape, structure, and size.

\subsubsection{Experimental Design of Soil Evaporation under Different Moisture Contents}

From June to December 2015, we selected 1-2 sunny days in each month and randomly selected one point from sample plots 16-20 in EU2. According to the method in Section 2.3.4, we collected five soil columns from each small evaporator and sprayed $0 \mathrm{~mL}, 47.5 \mathrm{~mL}, 95.0 \mathrm{~mL}, 142.5 \mathrm{~mL}$, and $190 \mathrm{~mL}$ of water on the soil columns in the evaporator, and the other operation methods were the same as those in Section 2.3.4. The weighing times were 7:30-8:00, 18:00-18:30, and 7:30-8:00 on the following day. Meanwhile, we used a $200 \mathrm{~cm}^{3}$ ring knife to sample soil at $0-16 \mathrm{~cm}$ in various fields to determine the soil water content. Finally, the soil water content in each treatment was calculated according to the original soil water content and the added water content.

\subsubsection{Statistical Analysis}

Statistical analyses were performed using analysis of variance (ANOVA) and Pearson's correlation analysis. All statistical analyses were performed in SAS version 6.12 (SAS Institute Inc., Cary, NC, USA) at $p<0.05$.

\section{Results}

\subsection{Control Effect of Herbicide and Mechanical Weeding on Undergrowth Plants}

Glyphosate, a potassium salt adjuvant and an internal absorption and conduction type of chronic broad-spectrum inactivation herbicide, was selected as the herbicide [38]. However, glyphosate herbicide has different effects on different weed species [39]. As shown in Tables 3 and 4, the control effects of herbicides were the best and fastest on Microstegium vagans (Nees ex Steud.) A. Camus, Dicranopteris dichotoma (Thunb.) Bernh, and Blechnum orientale. We can conclude that after 30 days of herbicide application, the three plants mostly withered and lasted for 60 days. However, on the 
100th day, the three plants regenerated to different degrees, and the recovery speed of Microstegium vagans (Nees ex Steud.) A. Camus was the fastest. The biomasses of EU1 and EU2 recovered to 33.0\% and $39.0 \%$ of the $C K$, respectively, followed by that of Blechnum orientale, which recovered to $28.0 \%$ and $26.0 \%$ of the CK, respectively. We found that the biomass of EU1 and EU2 recovered only $5.0 \%$. We found that the recovery of Dicranopteris dichotoma (Thunb.) Bernh was the slowest, and the biomass of Dicranopteris dichotoma (Thunb.) Bernh in EU1 and EU2 was only 5.0\%. Meanwhile, herbicides could also inhibit Gramineae such as Miscanthus floridulus (Lab.) Warb. ex Schum. et Laut. and Indocalamus tessellatus (Munro) Keng f. and shrubs such as Melastoma candidum D. Don and Rhodomyrtus tomentosa, but the effect was not as significant as that of herbaceous plants. We can conclude from Tables 3 and 4 that on the 10th day after herbicide application, the decline rates of Gramineae and shrub vegetation were less than $60 \%$, and the leaves of Melastoma candidum D. Don had not yet withered. However, after 30 days of herbicide application, the decline rate of Miscanthus floridulus (Lab.) Warb. ex Schum. et Laut. and Indocalamus tessellatus (Munro) Keng f. reached 65\%. In addition, after 100 days of herbicide application, all of the vegetation in EU1 and EU2 was restored to different degrees, of which Microstegium vagans (Nees ex Steud.) A. Camus was the fastest, from $0 \%$ on the 60 th day to over $33.0 \%$ on the 100th day. Therefore, herbicides could achieve good results, but not all plants could be treated. For example, glyphosate had no inhibitory effect on Dianella ensifolia, and the biomass of Dianella ensifolia continued to increase after application, which also showed that herbicides had poor effects on shrubs. Based on these results, we found that although herbicides could kill most of the roots of weeds, the deep roots receiving hybrid irrigation did not yet rot. We analyzed the possibility that the experiment adopted the method of spraying water on the leaf surface, so the agent was unable to penetrate into the root and stem; in addition, the dose of the agent did not reach the concentration that could kill the plant, and it was also possible that glyphosate was not suitable for control under miscellaneous irrigation methods.

Mechanical weeding is physical weeding that mainly refers to the use of a weeding machine to remove the aboveground part of vegetation to inhibit plant growth [40], while the survival mode and amount of roots underground vary by plant species, and roots do not necessarily die or rot. Tables 3 and 4 show that mechanical weeding could effectively remove vegetation in the early stage, and the vegetation biomass of EU1 and EU2 after 10 days was 0 . However, after 30 days of mechanical weeding, most of the plants exhibited different degrees of recovery, but all of them were within $7 \%$. We found that the recovery speed of herbaceous and pteridophyte plants was the fastest and that of shrubs was the slowest. Tables 3 and 4 show that after 30 days of mechanical weeding, the biomass of Microstegium vagans (Nees ex Steud.) A. Camus in EU1 and EU2 recovered to $9.9 \%$ and $14.0 \%$ of the CK, respectively, and the biomass of Blechnum orientale in EU2 recovered to $12.0 \%$ of the CK. On the 60th day after weeding, the biomasses of each plant were further increased. The biomass of Microstegium vagans (Nees ex Steud.) A. Camus, Miscanthus floridulus (Lab.) Warb. ex Schum. et Laut., and Dianella ensifolia in EU1 recovered to $45.0 \%, 40.0 \%$, and $34.9 \%$ of the CK, while EU2 recovered to $49.0 \%$, $44.0 \%$, and 39.0\%, respectively. Meanwhile, Blechnum orientale, Dicranopteris dichotoma (Thunb.) Bernh and Indocalamus tessellatus (Munro) Keng f. also recovered greatly. On the 100th day after mechanical weeding, the biomasses of Microstegium vagans (Nees ex Steud.) A. Camus, Miscanthus floridulus (Lab.) Warb. ex Schum. et Laut. and Dianella ensifolia in EU1 and EU2 exceeded 50\% of the CK. In particular, the biomass of Microstegium vagans (Nees ex Steud.) A. Camus in EU1 and EU2 recovered to $67.0 \%$ and $69.0 \%$ of the $C K$, respectively. In addition, the recovery of the shrubs Melastoma candidum D. Don and Rhodomyrtus tomentosa was slow, the vegetation coverage was $11 \%$ lower than CK on the 60 th day, and only $22 \%$ and $36-45 \%$ of CK on the 100 th day. 
Table 3. Biomass (g) change and total plant decline rate of EU1 after herbicide and mechanical weeding.

\begin{tabular}{|c|c|c|c|c|c|c|c|c|c|c|c|c|}
\hline \multirow{2}{*}{ Vegetation Types } & \multicolumn{3}{|c|}{$10 \mathrm{~d}$} & \multicolumn{3}{|c|}{$30 \mathrm{~d}$} & \multicolumn{3}{|c|}{$60 d$} & \multicolumn{3}{|c|}{$100 \mathrm{~d}$} \\
\hline & HW & MW & CK & HW & MW & CK & HW & MW & CK & HW & MW & CK \\
\hline Microstegium vagans (Nees ex Steud.) A. Camus & 0.0 & 0.0 & 30.2 & 0.0 & 4.6 & 45.6 & $0.0^{*}$ & 31.6 & 70.2 & $39.8^{*}$ & 80.9 & 120.7 \\
\hline Miscanthus floridulus (Lab.) Warb. ex Schum. et Laut. & $15.2 *$ & 0.0 & 25.3 & $14.1 *$ & 2.0 & 40.4 & $13.9 *$ & 25.3 & 63.2 & $21.5 *$ & 46.4 & 85.9 \\
\hline Dianella ensifolia & $22.5 *$ & 0.0 & 21.4 & $27.3 *$ & 1.5 & 25.8 & $31.4 *$ & 10.5 & 30.1 & $38.4 *$ & 18.4 & 35.4 \\
\hline Dicranopteris dichotoma (Thunb.) Bernh & $27.4^{*}$ & 0.0 & 39.1 & 0.0 & 2.3 & 46.1 & $0.6^{*}$ & 10.6 & 55.9 & $3.8 *$ & 30.2 & 75.5 \\
\hline Indocalamus tessellatus (Munro) Keng f. & $22.6 *$ & 0.0 & 25.1 & 11.8 * & 2.0 & 33.6 & 15.6 & 12.4 & 45.8 & 24.1 & 22.5 & 53.6 \\
\hline Melastoma candidum D. Don & $17.2 *$ & 0.0 & 15.8 & $13.7 *$ & 0 & 17.4 & $20.0 *$ & 1.5 & 25 & $27.2 *$ & 7.3 & 33.2 \\
\hline Rhodomyrtus tomentosa & $20.3^{*}$ & 0.0 & 24.1 & $17.1 *$ & 1.5 & 25.5 & $17.7 *$ & 2.6 & 28.6 & $23.6 *$ & 12.9 & 35.7 \\
\hline Blechnum orientale & $12.5^{*}$ & 0.0 & 21.2 & 3.2 & 2.6 & 28.7 & 5.4 & 9.6 & 35.7 & $15.5^{*}$ & 24.9 & 55.4 \\
\hline Total biomass $\left(\mathrm{g} / \mathrm{m}^{2}\right)$ & $137.5^{*}$ & 0.0 & 202.2 & $87.2 *$ & 16.6 & 263.1 & 104.5 & 104.1 & 354.5 & $193.9 *$ & 243.5 & 495.4 \\
\hline Total control efficacy ( $\%)$ & $32.0 *$ & 100.0 & & $66.9 *$ & 93.7 & & 70.5 & 70.6 & - & $60.9 *$ & 50.9 & \\
\hline
\end{tabular}

Note: The number after * indicates that there is a significant difference between HW and MW $(p<0.05)$.

Table 4. Biomass (g) change and total plant decline rate of EU2 after herbicide and mechanical weeding.

\begin{tabular}{|c|c|c|c|c|c|c|c|c|c|c|c|c|}
\hline \multirow{2}{*}{ Vegetation Types } & \multicolumn{3}{|c|}{ 10d } & \multicolumn{3}{|c|}{$30 \mathrm{~d}$} & \multicolumn{3}{|c|}{$60 d$} & \multicolumn{3}{|c|}{ 100d } \\
\hline & HW & MW & CK & HW & MW & CK & HW & MW & CK & HW & MW & CK \\
\hline Microstegium vagans (Nees ex Steud.) A. Camus & 0.0 & 0.0 & 32.7 & $0.0 *$ & 6.7 & 47.9 & 0.0 * & 36.5 & 74.5 & 44.6 * & 78.9 & 114.3 \\
\hline Miscanthus floridulus (Lab.) Warb. ex Schum. et Laut. & $18.5^{*}$ & 0.0 & 35.6 & 12.6 * & 4.2 & 52.6 & 15.9 * & 34.9 & 79.4 & 23.3 * & 63.9 & 101.4 \\
\hline Dianella ensifolia & 13.4 * & 0.0 & 15.2 & $15.1 *$ & 1.1 & 17.8 & 17.9 * & 8.9 & 22.8 & $22.3 *$ & 16.1 & 28.7 \\
\hline Dicranopteris dichotoma (Thunb.) Bernh & $30.5^{*}$ & 0.0 & 46.9 & $0.0 *$ & 4.3 & 53.2 & $1.4^{*}$ & 14.4 & 68.4 & $4.5^{*}$ & 38.1 & 90.7 \\
\hline Indocalamus tessellatus (Munro) Keng f. & $27.5^{*}$ & 0.0 & 32.4 & 13.4 * & 3.4 & 41.9 & 18.2 & 16.5 & 55.1 & 28.1 & 28.1 & 62.5 \\
\hline Melastoma candidum D. Don & $14.2 *$ & 0.0 & 12.8 & 11.0 * & 0.0 & 14.3 & 17.9 * & 1.4 & 22.7 & $25.5^{*}$ & 7.2 & 31.1 \\
\hline Rhodomyrtus tomentosa & $22.6 *$ & 0.0 & 19.4 & $14.8 *$ & 1.3 & 21.7 & $16.0^{*}$ & 2.8 & 25.4 & $21.2 *$ & 14.9 & 33.2 \\
\hline Blechnum orientale & $24.7^{*}$ & 0.0 & 47.5 & 4.7 & 7.0 & 58.3 & $9.1 *$ & 20.9 & 65.3 & $21.7 *$ & 41.0 & 83.6 \\
\hline Total biomass $\left(\mathrm{g} / \mathrm{m}^{2}\right)$ & $151.4^{*}$ & 0.0 & 242.5 & $71.6^{*}$ & 27.9 & 307.7 & $96.4 *$ & 136.3 & 413.6 & $191.3 *$ & 288.1 & 545.5 \\
\hline Total control efficacy (\%) & 37.6 * & 100.0 & & 76.7 * & 90.9 & & 76.7 * & 67.1 & & $64.9 *$ & 47.2 & \\
\hline
\end{tabular}

Note: The number after * indicates that there is a significant difference between HW and MW $(p<0.05)$. 
In general, the total amount of plant biomass under the Eucalyptus forest under herbicide weeding began to decline gradually after application and began to increase gradually after 30 days, but mechanical weeding could achieve $100 \%$ control at the beginning. Despite the initial results, the weeds recovered to varying degrees after increasing times of specific applications for both herbicide weeding and mechanical weeding. On the 60th day, there was little difference in biomass between herbicide and mechanical weeding in EU1 and EU2. In the first 60 days, the total control effect of herbicide weeding was significantly lower than that of mechanical weeding, but after 60 days, it was significantly higher than that of mechanical weeding. During the 100 days of the experiment, the increases in the vegetation biomasses (the increment from the minimum value to the maximum value during the period) of EU1 and EU2 was $106.7 \mathrm{~g} / \mathrm{m}^{2}$ and $119.7 \mathrm{~g} / \mathrm{m}^{2}$, respectively, while those of mechanical weeding were $243.5 \mathrm{~g} / \mathrm{m}^{2}$ and $288.1 \mathrm{~g} / \mathrm{m}^{2}$, respectively. Tables 3 and 4 also show that the increases in shrub biomass under herbicide weeding were $36.4 \%$ and $40.8 \%$ of the CK, while that of mechanical weeding was $80.4 \%$ and $95.1 \%$, respectively, which was approximately 2.2 times greater than that under herbicide weeding. In addition, we found that the weeding effect of EU2 was significantly better than that of EU1 because of its young age and low canopy density. The average value of four times the total control effect calculated by EU1 and EU2 was $57.6 \%$ and $64.0 \%$, respectively. EU1 was significantly lower than EU2 ( $<<0.05)$, but the total control effects of mechanical weeding were $78.8 \%$ and $76.3 \%$ for EU1 and EU2, respectively, which indicated that the speed of vegetation restoration under Eucalyptus forest was faster than that under EU1 after mechanical weeding.

\subsection{Characteristics of Soil Evaporation under Different Weeding Measures}

In this study, the soil evaporation rate of Eucalyptus plantations under different weeding methods was monitored by a small-scale evaporation instrument. The total number of observation days was 69 , with 8-11 days per month. The soil evaporation experiments required considerable physical work, but this monitoring method is relatively accurate and reduces many interference factors. As shown in Figure 3, different weeding methods had different effects on the soil evaporation of Eucalyptus plantations and showed obvious change trends. After mechanical weeding, the soil evaporation rate of Eucalyptus plantations immediately and rapidly increased to 1.4 times that of the CK on the second day, while the soil evaporation rate after herbicide weeding increased significantly on the fifth day (Figure 3). According to Figure 3, the three stages could be analyzed. In the 54 days after weeding (to 6 August 2015, the first stage), the average daily evaporation rate of soil moisture under mechanical weeding was $1.35 \mathrm{~mm} / \mathrm{d}$, which was $92.9 \%$ higher than that under the CK and $33.7 \%$ higher than that under herbicide weeding. During the period from the 61st day (12 August 2015) to the 139th day (29 October 2015) after weeding (the second stage), the daily average soil evaporation under mechanical weeding was $1.17 \mathrm{~mm} / \mathrm{d}, 61.6 \%$ and $30.1 \%$ higher than that under the CK and under herbicide weeding treatments, respectively. However, from 139 days after weeding (29 October 2015) to 200 days (29 December 2015, the third stage), the difference in the soil daily evaporation rate among the $\mathrm{CK}$, herbicide weeding, and mechanical weeding treatments was smaller than in the previous two stages. In this stage, the average daily evaporation was $0.52,0.48$, and $051 \mathrm{~mm} / \mathrm{d}$. We found that the soil evaporation under herbicide weeding was significantly lower than that under the CK and under mechanical weeding treatments $(p<0.05)$, but there was no significant difference between the CK and mechanical weeding treatments $(p>0.05)$. In addition, we found that the soil evaporation of EU2 was similar to that of EU1, but the first stage of EU2 was only 38 days, which was shorter than that of EU1. Meanwhile, the second stage of EU2 was 11 days longer than EU1, and the third stages of EU1 and EU2 were similar. Figure 4 shows that the evaporation of soil decreases with the increase of vegetation biomass and increases with the improvement of weeding control effect. Our results show that vegetation biomass slows down soil evaporation, and the rate of soil evaporation increases due to the bare surface after weeding. 

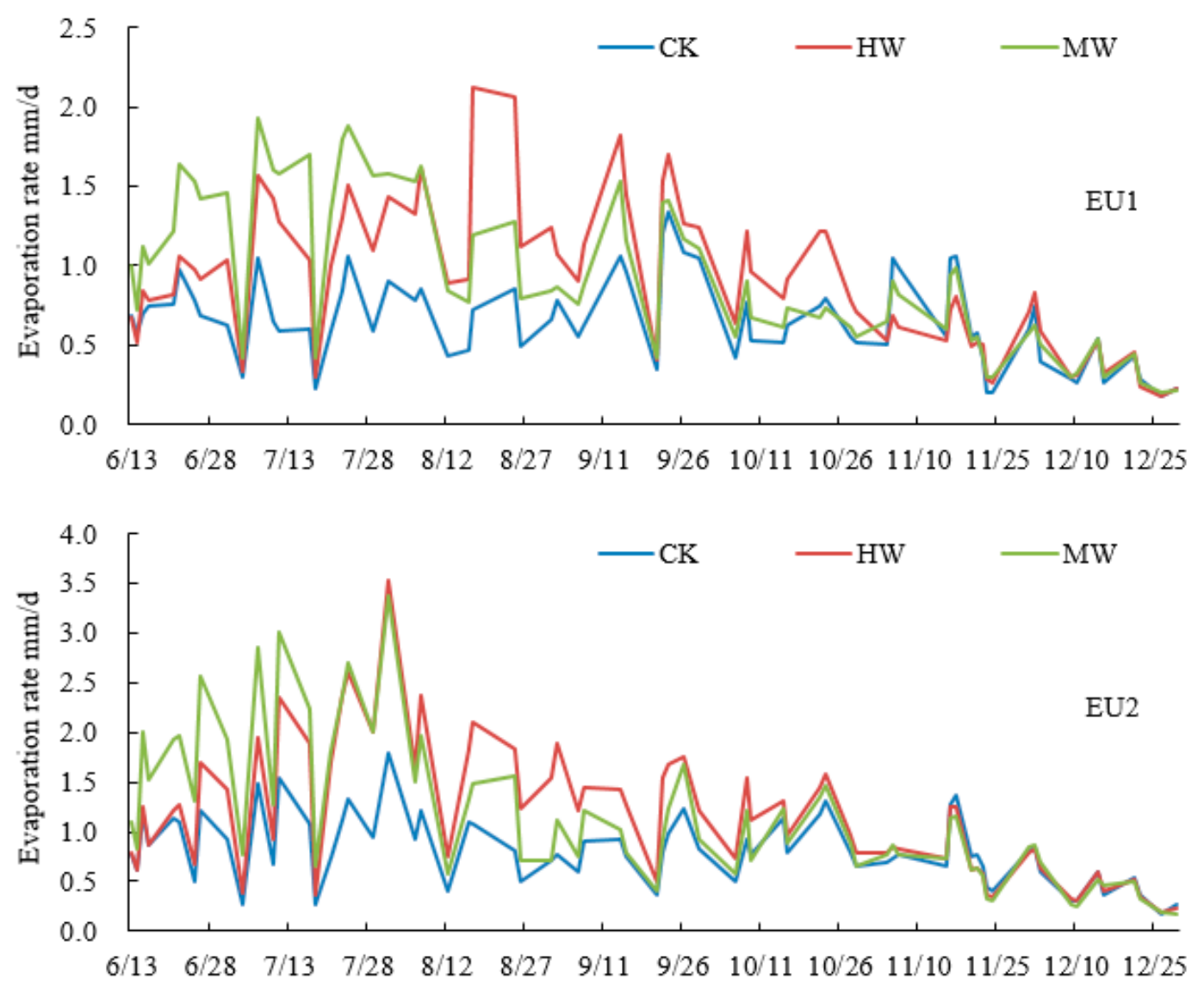

Figure 3. Soil evaporation rate of EU1 and EU2 under different weeding methods. Continuous lines of different colors show the change of soil evaporation between different weeding methods.

We analyzed the daily evaporation of soil in each month on average, expressed the evaporation intensity of that month with this average value, and calculated the percentage of the total evaporation over the whole observation period (200 days). As shown in Figure 5, in June and July, the soil evaporation intensity under mechanical weeding was significantly higher than those under the CK and under herbicide weeding treatments. The evaporation of EU1 and EU2 accounted for $40.0 \%$ and $43.5 \%$ of the total evaporation in the whole period (seven months), while those in the CK and under herbicide weeding accounted for $30.2 \%$ and $32.2 \%$ and $29.2 \%$ and $32.0 \%$, respectively. However, in August, September, and October, the soil evaporation rate of herbicide weeding was significantly higher than that of the CK and under mechanical weeding. In November and December, except for EU1 in November, the other plots showed no significant difference. From the analysis of the whole experimental process, on the 200 observed days, the average values of soil evaporation under herbicide weeding and mechanical weeding in EU1 and EU2 were 0.93 and $0.94 \mathrm{~mm} / \mathrm{d}$ and 1.20 and $1.19 \mathrm{~mm} / \mathrm{d}$, respectively. There was no significant difference between herbicide weeding and mechanical weeding, but the values under these treatments were significantly greater than those in the CK (the values in EU1 and EU2 were $0.66 \mathrm{~mm} / \mathrm{d}$ and $0.83 \mathrm{~mm} / \mathrm{d}$, respectively). The weeding of EU1 and EU2 was $40.1 \%$ and $43.4 \%$ higher, respectively, than that of non-weeding. 

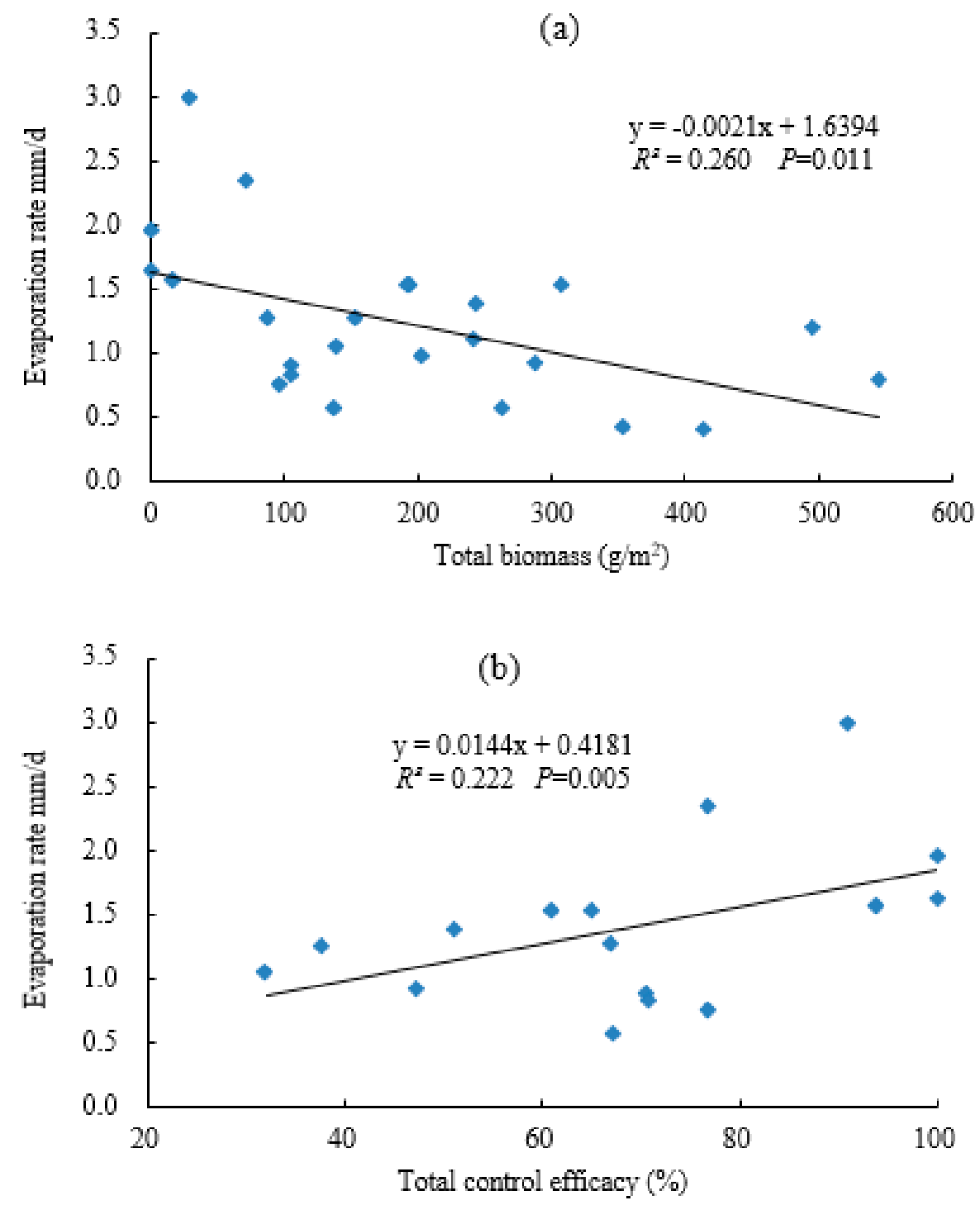

Figure 4. The relationship between total biomass (a), total control efficacy (b) and soil evaporation.

As shown in Figure 6, the average coefficient of variation of the soil daily evaporation rate in EU1 and EU2 was 29.6\% and 22.6\%, respectively, within 36 days after weeding (to 18 July 2015), which was significantly higher than that of the CK and under herbicide weeding. After July 18, the spatial variation in the soil daily evaporation rate under mechanical weeding gradually decreased and the difference between the CK and herbicide weeding gradually decreased. This result is due to the gradual restoration of vegetation, the increase in surface biomass, the weakening of the root system on soil pores, and the gradual stabilization of soil evaporation [41]. 


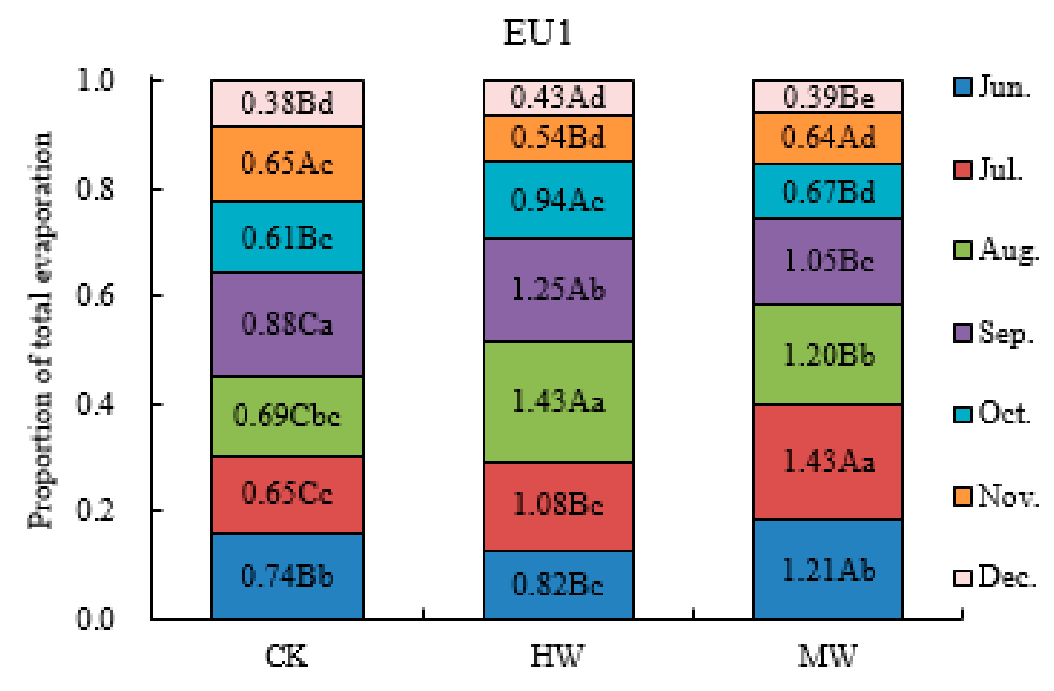

EU2

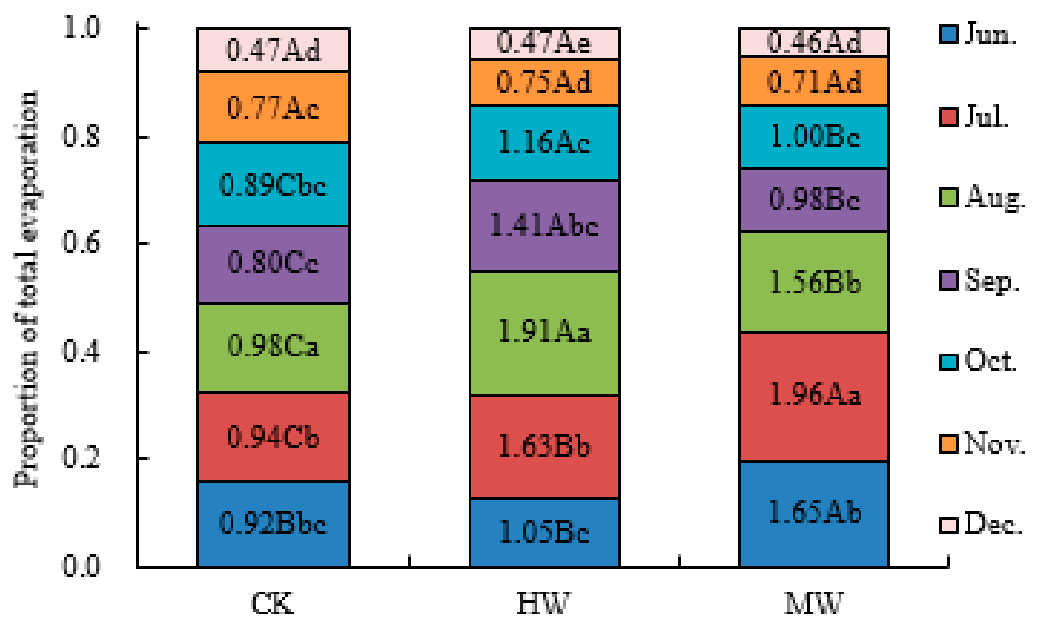

Figure 5. Daily mean value of soil evaporation of EU1 and EU2 under different weeding measures. Note: The figures in the figure show the average evaporation intensity $(\mathrm{mm} / \mathrm{d})$ of all observation days in each month, and the ordinate shows the percentage of evaporation in each month in the total evaporation in the whole observation period (200 d). Different capital letters after the numbers indicate that there is a significant difference in the daily mean value of soil evaporation among different treatments in the same month, while small letters indicate that there is a significant difference in the daily mean value of soil evaporation among different treatments in the same month $(p<0.05)$. 

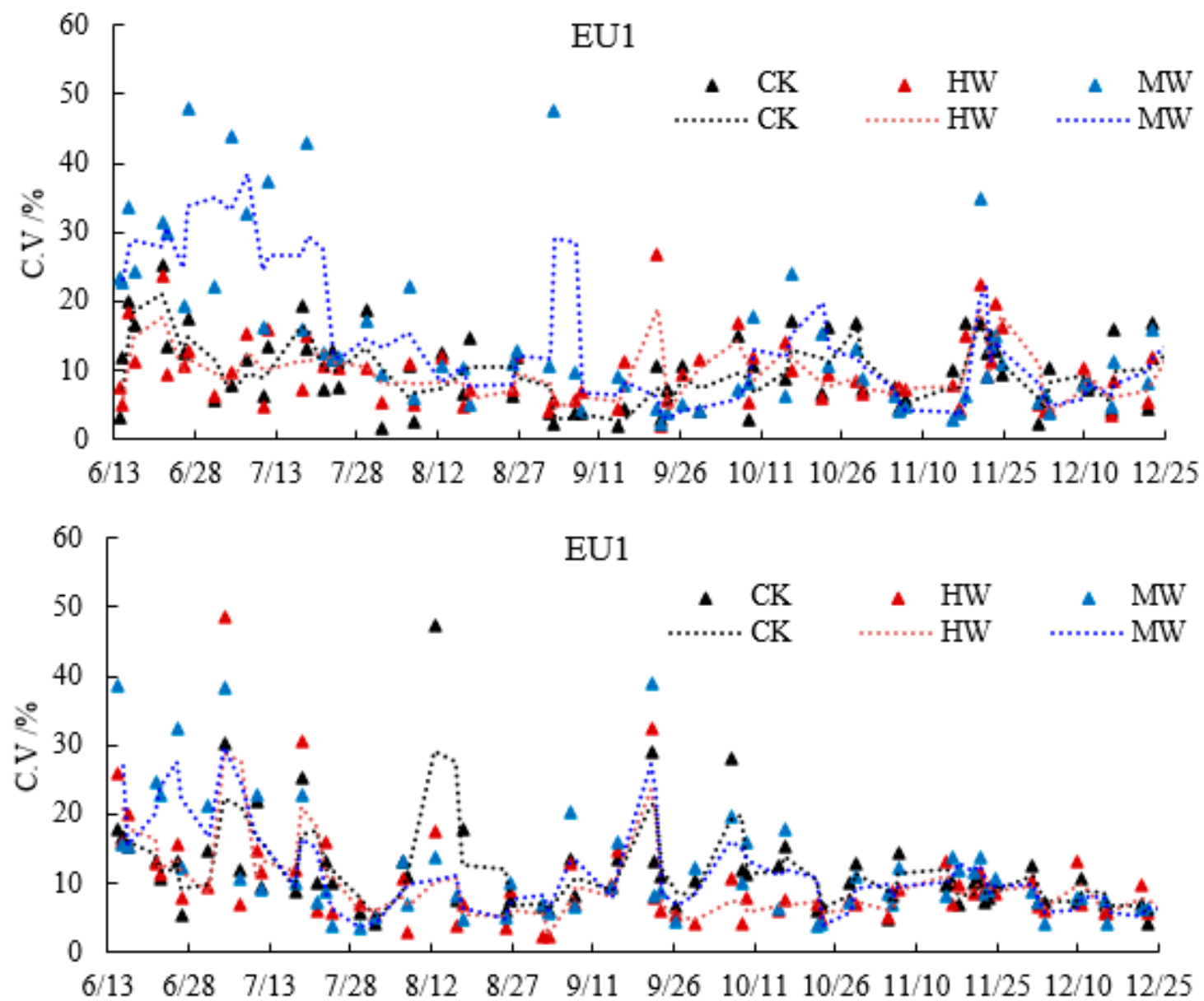

Figure 6. Spatial variability of soil evaporation rate under different weeding treatments. Note: The dotted line in the figure is the moving average line.

\subsection{Effect of Different Water Contents on the Soil Evaporation of Eucalyptus Plantations}

Weeding directly affects vegetation biomass and coverage, which will inevitably affect the rate of rainfall into the soil and water content. To study the effect of different moisture contents on the soil evaporation of Eucalyptus plantations, 0.0, 47.5, 95.0, 142.5, or $190 \mathrm{~mL}$ of water was injected into the soil column of the evaporator for 1-2 days. As shown in Figure 7, we selected one or two days of observation every month from June (twice in November), a total of eight times, and compared the soil evaporation in the daytime with that in the evening. We found that the change trends during the daytime and at night were similar. With the increase in the initial soil moisture content, the soil evaporation rate showed an overall increasing trend. However, we also found that when the water content was $28 \%$, an inflection point appeared in the soil evaporation rate. During the daytime, when the initial moisture content was less than $28 \%$, the evaporation rate increased with increasing initial moisture content. When the initial moisture content was greater than $28 \%$, the evaporation rates of D1, D2, D3, and D4 showed different trends with increasing initial moisture content and remained basically stable. D5 and D6 gradually showed downward trends when the initial moisture content was greater than 33\%, while D7 and D8 continued to increase after the initial moisture content was greater than $33 \%$. The change trends of soil evaporation and initial moisture content at night were similar to those during the day. The difference was that after the initial moisture content of D7 and D8 was greater than $33 \%$, the soil evaporation rate increased with increasing initial moisture content. The reason for the above changes is that D1-D4 occurred in the summer, when the temperature is higher during the daytime than at night, and the relative humidity of air is consistently high, so the evaporation remains mostly stable. However, D7 and D8 occurred in winter, when the air is relatively 
dry, the air flow is high, and the wind speed is faster, so the evaporation rate of soil increases with the increase in the initial soil moisture content.
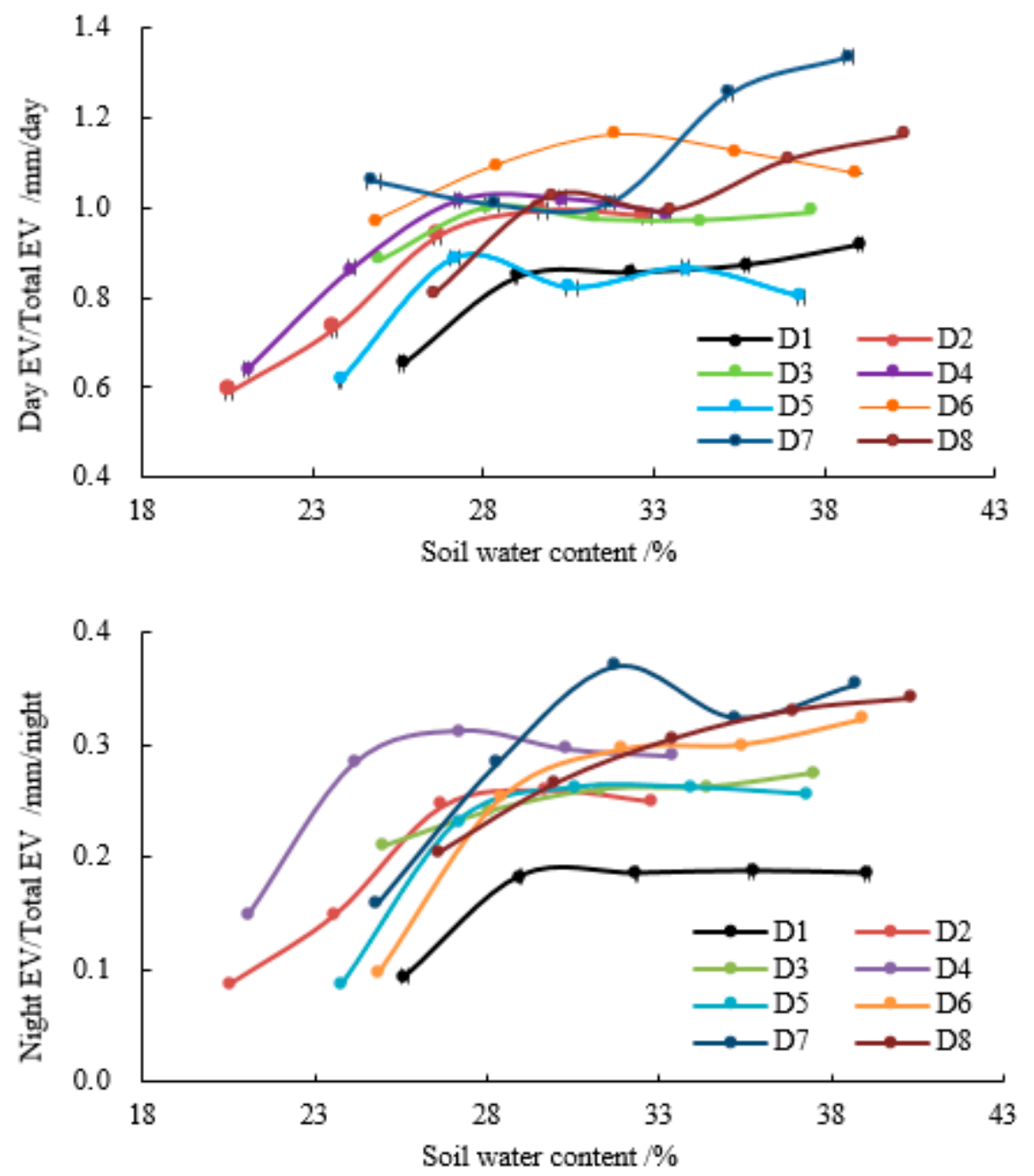

Figure 7. Effect of initial water content on soil evaporation of Eucalyptus forest in day and night. Continuous lines of different colors represent different monitoring times. D1 to D8 indicate eight times of monitoring.

In addition, as shown in Figure 8, the evaporation rate of soil increased with the increase in the initial moisture content during both the day and night and showed a significant correlation. To further understand the relationship between them, we also analyzed the ratio of soil evaporation at night to the evaporation throughout the day and the initial moisture content and found that the ratio also increased with the increase in the initial moisture content (Figure 8). The reason for these phenomena is that the surface area of the initial water content contacting the air increases, and the evaporation capacity will also accelerate. From this point of view, weeding has a great impact on the soil evaporation of Eucalyptus plantations, and the vegetation coverage of weeding is reduced, especially in the early stage of mechanical weeding, which causes rainfall to directly reach the ground, so the evaporation rate differs for soil with different initial water contents. However, after chemical weeding, although temporarily covered by vegetation, the vegetation coverage changes greatly in this process, generally showing a trend of decreasing first and then increasing, which results in different soil evaporation, which has different effects on the water loss of Eucalyptus plantations. Previous studies have shown that Eucalyptus has strong photosynthetic capacity and less water consumption than other plantations. The results of Food and Agriculture Organization of the United nNations (FAO) showed that the water consumption per $1 \mathrm{~kg}$ of Eucalyptus was $510 \mathrm{~L}$, Leucaena was $580 \mathrm{~L}$, and conifer was $1000 \mathrm{~L}$. Similar 
results have also been found that the water consumption per $1 \mathrm{~kg}$ of Eucalyptus is $758 \mathrm{~L}$, which is far lower than $1538 \mathrm{~L}$ of pine and $1323 \mathrm{~L}$ of Acacia. [42]. Therefore, the belief that "Eucalyptus is a pump" is considered to not be scientific, but practical measures should be taken to solve the problem of water consumption in production practice. In view of the research results in this field, we also suspect that soil evaporation is one of the reasons for the decrease of runoff Eucalyptus plantations [18-20]
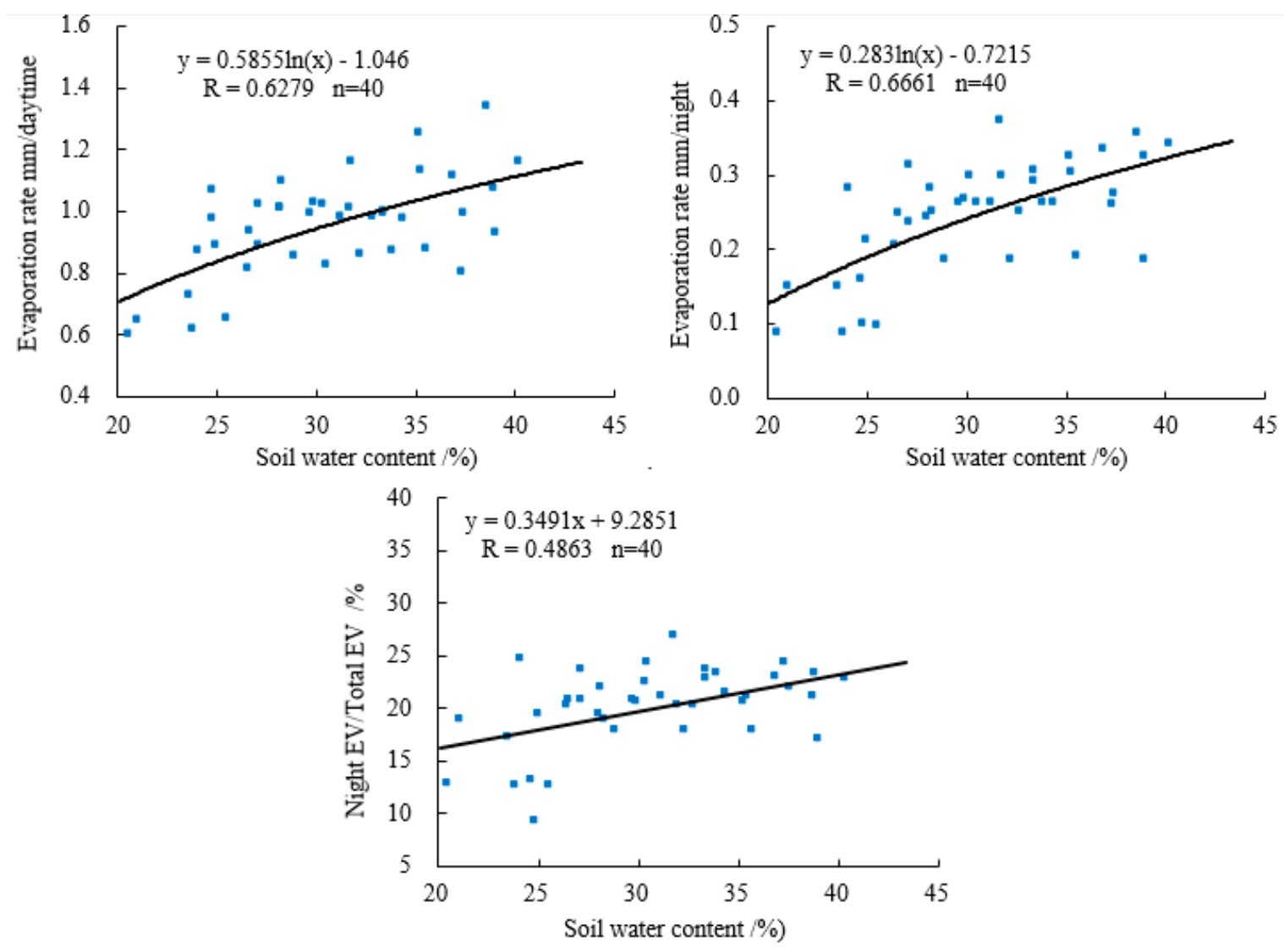

Figure 8. The relationship between the initial moisture content and the percentage of evaporation at night.

\subsection{Effect of Different Weeding Measures on Eucalyptus Growth}

However, the weeding of Eucalyptus plantations is necessary and effective. Figures 9-11 show that weeding could significantly promote the height, DBH, and volume of Eucalyptus. We found that the tree height, $\mathrm{DBH}$, and volume under herbicide or mechanical weeding were significantly higher than those under non-weeding after one month (July). With increasing duration, the differences in the height, DBH, and volume between herbicide weeding, mechanical weeding, and the CK gradually expanded. Our results showed that after 200 days of weeding (December 2015), the Eucalyptus heights in EU1 and EU2 were 1.11 and 1.21 times that in the CK, the DBH was 1.15 and 1.25 times greater, and the volume was 1.42 and 1.69 times greater than those in EU1 and EU2, respectively. Although the height of Eucalyptus trees weeded by EU2 in August 2015 was significantly lower than that weeded by mechanical weeding, the effects of herbicide weeding and mechanical weeding on the height, DBH, and volume of Eucalyptus trees were not significant. In addition, Eucalyptus was also found to grow fastest from July to October under different weeding treatments, while it grew slowest from October to December. This result is because the overall water condition in summer is the best, the temperature is most suitable for Eucalyptus growth, and the role of weeding will also be reflected in the early stage. However, for the treatment without weeding, the growth was significantly lower than that in the two weeding treatments beginning in July, especially in the tree volumes of EU1 and EU2 (Figure 11). Although the growth patterns were similar, the growth speed of trees under the CK was lower than 
that under the weeding treatments. The reason why the growth of Eucalyptus plantations was not significantly different is that both treatments reduced the competition of Eucalyptus for nutrients [43].
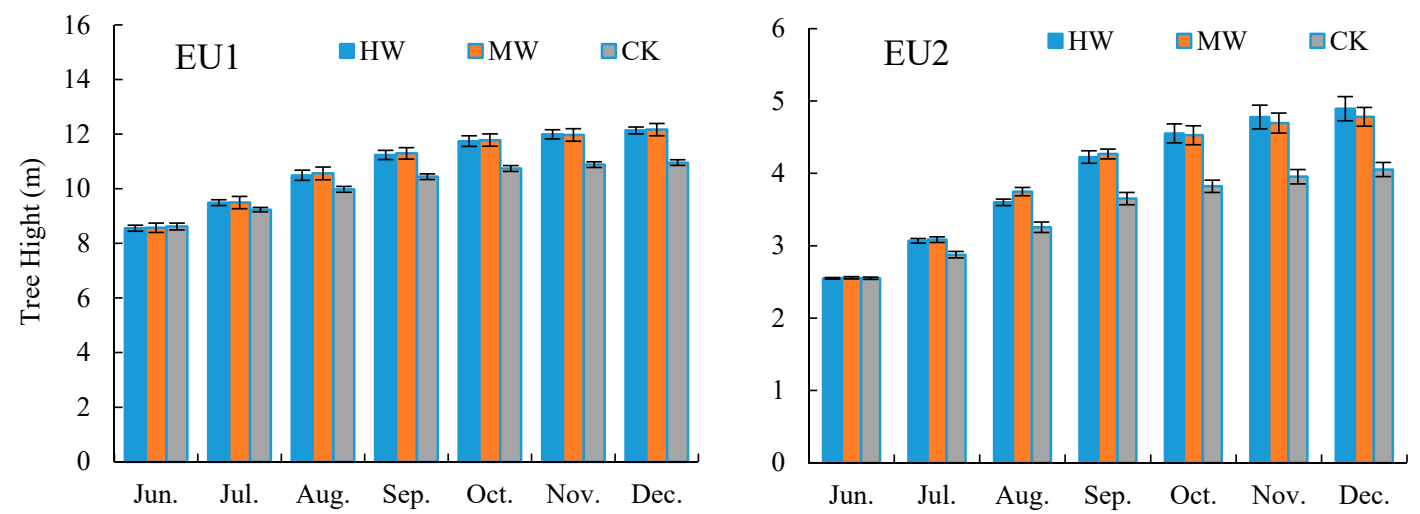

Figure 9. Height growth change of Eucalyptus under different weeding methods.
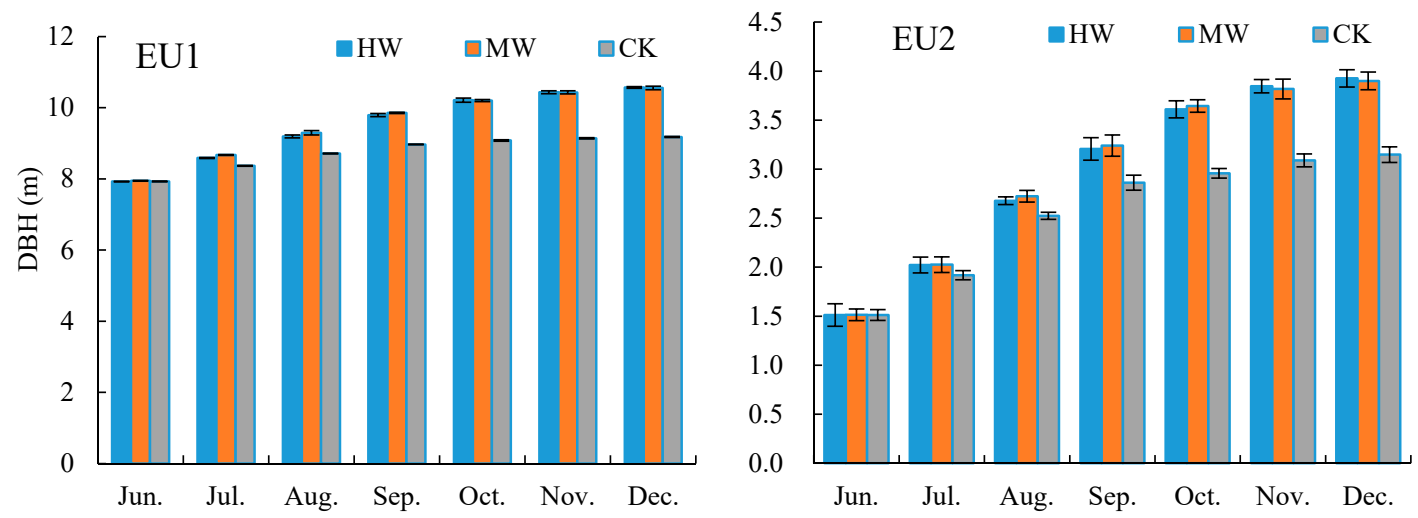

Figure 10. Change of Eucalyptus diameter at breast height growth under different weeding methods.
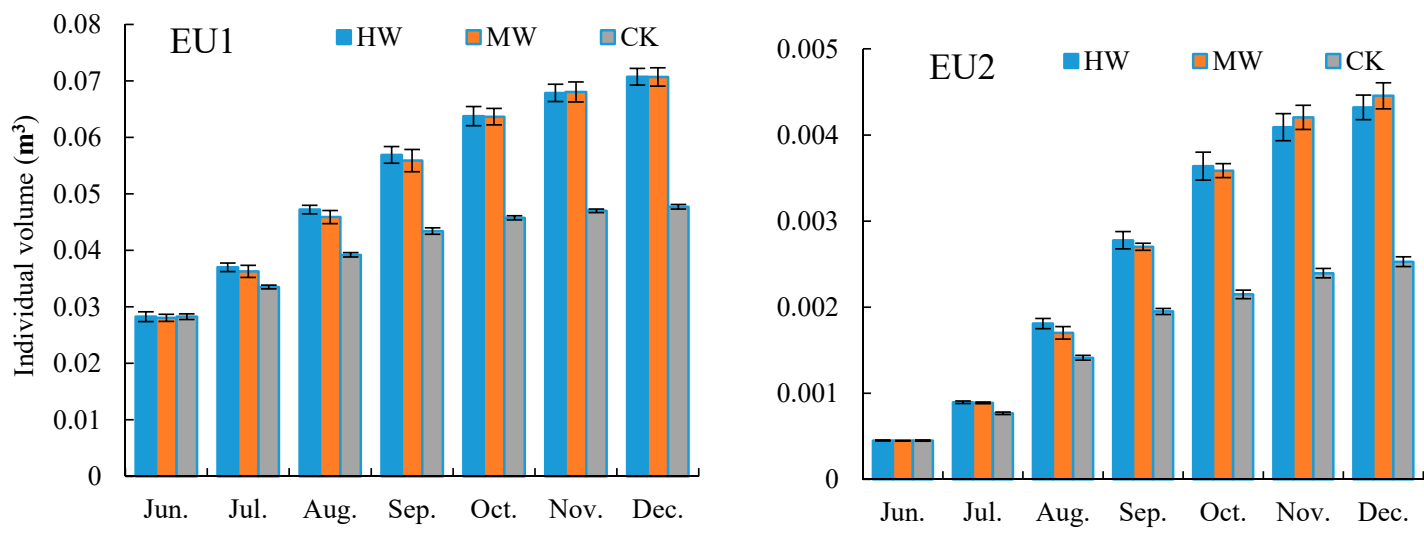

Figure 11. Volume change of Eucalyptus under different weeding methods.

\section{Discussion}

Throughout the weeding cycle, the average daily evaporation of each month varied under the different weeding treatments, which may be related to the climate of each season and the weeding mechanisms $[10,44]$. In June and July, the soil evaporation under the herbicide treatment was less than that under the mechanical weeding treatment, which may be because some weeds sensitive to herbicide were just beginning to wilt after herbicide spraying. With the gradual effect of herbicides, weeds began to wither and fall over a large area in August. Under the herbicide weeding treatment, the water potential difference between the soil surface and the air increased due to the bare soil surface, and the soil evaporation increased rapidly, which was significantly higher than that under the mechanical 
weeding and non-weeding treatments [45]. However, after mechanical weeding, the root system of vegetation remained in the soil, and it began to grow again in August. The weeds spread on the surface weakened the intensity of the exchange between the air and the atmosphere, which reduced water loss and achieved water conservation [46]. On cloudy and rainy days in August, September, October, and November, the average daily evaporation and water consumption of the soil treated with herbicide were higher than those under the mechanical weeding and non-weeding treatments. Rainfall results in an increase in soil moisture content, which fills the soil pores and moves to the surface mainly through capillary action [47]. The effect of meteorology on water transport at the soil surface increases with the increase in bare surface area, and the temperature difference and wind speed between the soil and the sky play a leading role in evaporation [48]. Therefore, the evaporation from the herbicide weeding sample plot was stronger than that from the mechanical weeding plot, while the evaporation from the non-weeding sample plot was the smallest. Another reason for this difference is that during rainfall, the hay cover over the herbicide weeding sample land played a role in intercepting rainwater, which blocked the pore channels or soil water infiltration and reduced the infiltration rate of gravity water in the upper soil, resulting in water being mostly distributed in the surface soil and hay and being highly affected by temperature and wind speed [49]. In addition, capillary water continuously moves during the process of rainfall. After the surface soil water evaporates, the water in the lower layers quickly makes up for the water deficits in the upper layers [50]. Litter cover adds a physical barrier layer that prevents evaporation from the soil surface. Therefore, the daily average evaporation from the herbicide sample plots slowly increased after rainfall. After continuous sunshine, the litter and soil surface quickly lost water, and the evaporation exceeded that of the other two treatments. In November, the order of the average daily evaporation from the three groups was herbicide treatment $<$ mechanical weeding < non-weeding. Meteorological data from the study area show that September is generally the month with sharp rainfall reductions. Over 50 years (1961-2010), there were 47-52 days without precipitation from September to October, while little precipitation occurred from October to November, accounting for $18.5 \%$ of the precipitation from June to August. The daily average temperature decreased by $7{ }^{\circ} \mathrm{C}$ and the daily average sunshine decreased by $1.2 \mathrm{~h}$. Considering the water consumption from soil evaporation in June and July, there was no continuous precipitation to supplement soil water, the ability of solar radiation and air temperature to drive soil evaporation was reduced, and the power of upward transportation of deep water was insufficient. The surface of the mechanical weeding sample plot was exposed over a large area, while the herbicide sample plot was covered with dead grass, which weakened the effect of wind on soil evaporation [51,52]. In addition, the soil water inventory was similar for all kinds of weeding land. After the weeding treatment, the total soil water consumption of the land under the weeding treatment was largest during the rainy season, and the residual soil water was less than that under the non-weeding treatment, which is also why the average daily evaporation of the non-weeding treatment sample land was greater than that of the weeding sample land in the late observation periods. Weeding increased the output of soil water. On sunny days with low soil water content or reduced precipitation, the soil water consumption of the mechanical weeding and herbicide weeding sample plots was higher than that of the non-weeding plots, and the relatively bare mechanical weeding sample plots and the herbicide sample plots with litter cover exhibited certain water holding capacity [53]. On rainy days, withered grass retained additional water. After rainfall, the mulch of the withered grass slowed soil evaporation. After continuous sunny days, the withered grass lost much water, and the evaporation of forestland rapidly increased. In autumn, the effect of meteorological factors on soil evaporation is weakened, the evapotranspiration of forestland mainly depended on the transpiration of vegetation, and the soil water inventory of the sample plot without weeding was the largest, resulting in the maximum daily evaporation and total water consumption of the sample plot without weeding. In addition, both herbicide weeding and mechanical weeding promoted the formation of soil macropores [54-56] and had important impacts on soil evaporation and tree growth, which will be further discussed in the future. 
Runoff is the most important type of water resource that the forests provide for residents' lives and social production [57]. The change in the soil water storage function of forestland directly affects runoff and the spatial and temporal distribution of rainfall. At present, the interference of Eucalyptus plantation management measures on soil and vegetation is more intense and frequent than before and in other plantations [25], and the change in the soil water storage function may be extremely significant. In addition, because the changes in the leaf area index and shrub grass coverage between years and seasons in Eucalyptus plantations are faster than those in other forests, and the soil of forestland is strongly disturbed, soil evaporation is likely to be the key water process that will result in Eucalyptus plantations having different impacts on water resources than other forests [10,58,59]. Although the proportion of Eucalyptus plantations in the total forest area in China is not high (approximately 12.7\% in the Guangxi region and 6.0\% in Guangdong Province), the influence of Eucalyptus plantations on the total water resources in these regions may be small, but Eucalyptus plantations are regional. In some areas, Eucalyptus forests cover more than $50 \%$ of the total forest area, so the threat to regional water security posed by the planting of Eucalyptus trees cannot be eliminated [60]. It should be emphasized that the effect of vegetation change on runoff yield is closely related to weather conditions, even though Eucalyptus trees have little effect on the total annual runoff. Under special or extreme weather conditions, the effects of soil evaporation on ecohydrological processes may be amplified, resulting in significant impacts to water use in Eucalyptus forests and downstream areas at that time.

There is no doubt that both mechanical weeding and chemical weeding can achieve the goal of reducing weeds on the surface, especially because chemical weeding can inhibit the growth of roots to a certain extent, which reduces the total amount of soil nutrients absorbed by weeds and is conducive to the growth of Eucalyptus. Although some roots can survive after mechanical weeding, the reduction in surface biomass also greatly reduces the absorption of soil nutrients. In addition, the root system plays an important role in soil evaporation and water transport, which is due to the influence of changes in the shape and distribution of plant roots on the physical properties of soil [56]. Previous studies have shown that roots mainly increase the number of soil macropores and promote the connectivity between soil pores, which leads to changes in soil structure, soil macropores, soil water holding capacity, and water conductivity [55]; in particular, the dead roots formed by weeding promote the formation of soil macropores. Herbicide weeding or mechanical weeding will cause root death, especially herbicide weeding, which is an inactivated weeding method. In this case, macropores not only promote soil evaporation, but also provide more transport channels for water to enter the soil. Under the condition of sufficient water, Eucalyptus has many channels for water acquisition, which is also the reason for the increase in Eucalyptus growth. In addition, Eucalyptus forest management also adopts the method of mountain refining, which actually has the same effect as weeding, reducing the consumption of nutrients by weeds, and returning more nutrients to the soil, which is conducive to the growth of trees $[61,62]$. However, during mountain refining the surface humus layer is destroyed many times, and the organic culture branch decreases substantially. Therefore, weeding may be more appropriate. It is beneficial not only to increase the nutrients of forestland and promote the early growth of forest trees, but also to protect vegetation and improve the productivity of forestland.

\section{Conclusions}

In this study, we selected different methods for weeding Eucalyptus plantations to study the changes in vegetation biomass, soil evaporation rate, and Eucalyptus growth after weeding. We reached an interesting conclusion that both weeding methods can effectively remove weeds. Mechanical weeding has an obvious effect in the early stage, but the time of vegetation restoration after mechanical weeding is faster than that after herbicide weeding. Meanwhile, herbicide weeding is more effective for herbs but less effective for shrubs. Compared with non-weeding, mechanical weeding and herbicide weeding can significantly increase the soil evaporation rate of Eucalyptus plantations, but the effect is different. The soil evaporation rate increases immediately after mechanical weeding, but after herbicide weeding, the soil evaporation rate is higher than that after mechanical weeding after a period 
of time, and the ultimate difference decreases gradually. The rate of soil evaporation is also closely related to the initial water content of the soil. The higher the initial water content is, the higher the soil evaporation is, and the same change trend appears during the daytime and at night. In addition, weeding can significantly improve the growth of Eucalyptus. In the future, the relationship between weeding, soil infiltration and Eucalyptus growth will be further studied to enrich the hydrological processes in Eucalyptus plantations.

Author Contributions: Conceptualization, G.Y.; methodology, G.Y.; software, Y.D. and J.Y.; formal analysis, Y.D., Z.X. and J.Y.; resources, D.J. and Z.H.; writing - original draft preparation, Y.D. and G.Y.; writing-review and editing, Y.D. and Z.X.; project administration, G.Y., D.J. and Z.H. All authors have read and agreed to the published version of the manuscript.

Funding: Financial support was provided by the National Key Research and Development Program of China (No. 2017YFC0505402) and the National Natural Science Foundation of China (Grant No. 31360134, 40861025), Guangxi innovation driven development project (Grant No. GKAA17204078-3, GKAA17204087-8).

Conflicts of Interest: The authors declare no conflict of interest.

\section{References}

1. Cossalter, C.; Pye-Smith, C. Fast-Wood Forestry: Myths and Realities; Center for International Forestry Research: Bogor, Indonesia, 2003.

2. Hubbard, R.M.; Stape, J.; Ryan, M.G.; Almeida, A.C.; Rojas, J. Effects of irrigation on water use and water use efficiency in two fast growing Eucalyptus plantations. For. Ecol. Manag. 2010, 259, 1714-1721. [CrossRef]

3. Wen, Y.G.; Zhou, X.G.; Yu, S.F.; Zhu, H.G. The predicament and countermeasures of development of global Eucalyptus plantations. Guangxi Sci. 2018, 25, 107-116. (In Chinese)

4. Yang, G.R.; Shi, X.H.; Cai, D.S.; Huang, C.B.; Lei, S.M.; Zhang, H. Water quality of throughfall and stemflow in planted forest in Guangxi, China. J. Food Agric. Environ. 2011, 9, 947-953.

5. O' Connell, A.M.; Grove, T.S.; Mendham, D.S.; Rance, S.J. Impact of harvest residue management on soil nitrogen dynamics in Eucalyptus globulus plantations in south western Australia. Soil Biol. Biochem. 2004, 36, 39-48. [CrossRef]

6. Fernández, C.; Vega, J.A.; Gras, J.M.; Fonturbel, T.; Cuinas, P.; Dambrine, E.; Alonso, M. Soil erosion after Eucalyptus globulus clearcutting: Differences between logging slash disposal treatments. For. Ecol. Manag. 2004, 195, 85-95. [CrossRef]

7. Wilson, G.W.; Fredlund, D.G.; Barbour, S.L. Coupled soil-atmosphere modelling for soil evaporation. Can. Geotech. J. 1993, 31, 151-161. [CrossRef]

8. Li, T.C.; Shao, M.A.; Jia, Y.H. Characteristics of soil evaporation and temperature under aggregate mulches created by burrowing ants. Soil Sci. Soc. Am. J. 2017, 81, 114-123. [CrossRef]

9. Lauenroth, W.K.; Bradford, J.B. Ecohydrology and the partitioning AET between transpiration and evaporation in a semiarid steppe. Ecosystems 2006, 9, 756-767. [CrossRef]

10. Lawrence, D.M.; Thornton, P.E.; Oleson, K.W.; Bonan, G.B. The partitioning of evapotranspiration into transpiration, soil evaporation, and canopy evaporation in a GCM: Impacts on land-atmosphere interaction. J. Hydrometeorol. 2007, 8, 862-880. [CrossRef]

11. Chattopadhyay, N.; Hulme, M. Evaporation and potential evapotranspiration in India under conditions of recent and future climate change. Agric. For. Meteorol. 1997, 87, 55-73. [CrossRef]

12. Donohue, R.J.; McVicar, T.R.; Roderick, M.L. Assessing the ability of potential evaporation formulations to capture the dynamics in evaporative demand within a changing climate. J. Hydrol. 2010, 386, 186-197. [CrossRef]

13. Biederman, J.A.; Harpold, A.A.; Gochis, D.J.; Ewers, B.E.; Reed, D.E.; Papuga, S.A.; Brooks, P.D. Increased evaporation following widespread tree mortality limits streamflow response. Water Resour. Res. 2014, 50, 5395-5409. [CrossRef]

14. McNaughton, K.G.; Jarvis, P.G. Predicting effects of vegetation changes on transpiration and evaporation. Water Deficits Plant Growth 1983, 7, 1-47.

15. Davidson, E.A.; Savage, K.V.L.V.; Verchot, L.V.; Navarro, R. Minimizing artifacts and biases in chamber-based measurements of soil respiration. Agric. For. Meteorol. 2002, 113, 21-37. [CrossRef] 
16. Stannard, D.I.; Weltz, M.A. Partitioning evapotranspiration in sparsely vegetated rangeland using a portable chamber. Water Resour. Res. 2006, 42, 18-27. [CrossRef]

17. Rousseaux, M.C.; Figuerola, P.I.; Correa-Tedesco, G.; Searles, P.S. Seasonal variations in sap flow and soil evaporation in an olive (Olea europaea L.) grove under two irrigation regimes in an arid region of Argentina. Agric. Water Manag. 2009, 96, 1037-1044. [CrossRef]

18. Bosch, J.M.; Hewlett, J.D. A review of catchment experiments to determine the effect of vegetation changes on water yield and evapotranspiration. J. Hydrol. 1982, 55, 3-23. [CrossRef]

19. Almeida, A.C.; Soares, J.V.; Landsberg, J.J.; Rezende, G.D. Growth and water balance of Eucalyptus grandis hybrid plantations in Brazil during a rotation for pulp production. For. Ecol. Manag. 2007, 251, 10-21. [CrossRef]

20. Rodríguez-Suárez, J.A.; Soto, B.; Perez, R.; Diaz-Fierros, F. Influence of Eucalyptus globulus plantation growth on water table levels and low flows in a small catchment. J. Hydrol. 2011, 396, 321-326. [CrossRef]

21. Ward, S.M.; Cousens, R.D.; Bagavathiannan, M.V.; Barney, J.N.; Beckie, H.J.; Busi, R.; Gallandt, E.R. Agricultural weed research: A critique and two proposals. Weed Sci. 2014, 62, 672-678. [CrossRef]

22. Wiltshire, J.J.J.; Tillett, N.D.; Hague, T. Agronomic evaluation of precise mechanical hoeing and chemical weed control in sugar beet. Weed Res. 2003, 43, 236-244. [CrossRef]

23. Song, B.K.; Chuah, T.S.; Tam, S.M.; Olsen, K.M. Malaysian weedy rice shows its true stripes: Wild Oryza and elite rice cultivars shape agricultural weed evolution in Southeast Asia. Mol. Ecol. 2014, 23, 5003-5017. [CrossRef] [PubMed]

24. Gourley, M.; Vomocil, M.; Newton, M. Forest weeding reduces the effect of deer-browsing on douglas fir. For. Ecol. Manag. 1990, 36, 177-185. [CrossRef]

25. Garau, A.M.; Ghersa, C.M.; Lemcoff, J.H.; Barañao, J.J. Weeds in Eucalyptus globulus subsp. Maidenii (F. Muell) establishment: Effects of competition on sapling growth and survivorship. New For. 2009, 37, 251-264. [CrossRef]

26. Van der Weide, R.Y.; Bleeker, P.O.; Achten, V.T.J.M.; Lotz, L.A.P.; Fogelberg, F.; Melander, B. Innovation in mechanical weed control in crop rows. Weed Res. 2008, 48, 215-224. [CrossRef]

27. Ma, X.; Qi, L.; Liang, B.; Tan, Z.; Zuo, Y. Present status and prospects of mechanical weeding equipment and technology in paddy field. Trans. Chin. Soc. Agric. Eng. 2011, 27, 162-168.

28. Owen, M.D.; Zelaya, I.A. Herbicide-resistant crops and weed resistance to herbicides. Pest Manag. Sci. 2005, 61, 301-311. [CrossRef]

29. Beckie, H.J. Herbicide-resistant weeds: Management tactics and practices. Weed Technol. 2006, $20,793-814$. [CrossRef]

30. Green, J.M.; Owen, M.D. Herbicide-resistant crops: Utilities and limitations for herbicide-resistant weed management. J. Agric. Food Chem. 2010, 59, 5819-5829. [CrossRef]

31. Chen, L.; Huang, Z.; Gong, J.; Fu, B.; Huang, Y. The effect of land cover/vegetation on soil water dynamic in the hilly area of the Loess Plateau, China. Catena 2007, 70, 200-208. [CrossRef]

32. Chen, C.L.; Luo, X.L.; Zhang, J.Q.; Zhu, G.L.; Jin, G.R. Effect and economic benefits of seeding amount and weeding methods on kenaf growth and soil available nutrients. Acta Agric. Zhejiangensis 2015, 27, 1692-1697. (In Chinese)

33. Lei, L. Effects of Different Weed Control Methods on Ecological Environment, the Growth and Development and Yield of Cotton. Master's Thesis, Henan Agriculture University, Zhengzhou, China, June 2017. (In Chinese).

34. Tan, C.L.; He, B. Effects of Different Tending Methods on Growth of Young Cunning hamia lanceolata Plantation. J. Anhui Agric. 2009, 37, 17166-17167. (In Chinese)

35. Benayas, J.M.R.; Navarro, J.; Espigares, T.; Nicolau, J.M.; Zavala, M.A. Effects of artificial shading and weed mowing in reforestation of Mediterranean abandoned cropland with contrasting Quercus species. For. Ecol. Manag. 2005, 212, 302-314. [CrossRef]

36. Cen, J.Y. Study on two-way tree volume dynamic model of eucalyptus plantations in Guangxi. J. South China Agric. Univ. 2007, 28, 91-95.

37. Figuerola, P.I.; Rousseaux, M.C.; Searles, P.S. Soil evaporation beneath and between olive trees in a non-Mediterranean climate under two contrasting irrigation regimes. J. Arid Environ. 2013, 97, 182-189. [CrossRef] 
38. Duke, S.O.; Powles, S.B. Glyphosate: A once in a century herbicide. Pest Manag. Sci. 2008, 64, 319-325. [CrossRef]

39. Doĝan, M.N.; Öĝüt, D.; Mülleder, N.; Boz, Ö.; Brants, I.; Voegler, W. Effect of water volume and water quality on the efficacy of glyphosate on some important weed species in turkey. Julius-Kühn-Archiv 2012, 434, 229-234.

40. Buhler, D.D.; Doll, J.D.; Proost, R.T.; Visocky, M.R. Integrating mechanical weeding with reduced herbicide use in conservation tillage corn production systems. Agron. J. 1995, 87, 507-512. [CrossRef]

41. Wu, J.; Cui, N.X.; Cheng, S.P. Effects of sediment anoxia on growth and root respiratory metabolism of iris pseudacorus: Implications for vegetation restoration of eutrophic waters in China. Ecol. Eng. 2013, 53, 194-199. [CrossRef]

42. Huang, G.Q.; Zhao, Q.G. The history, status quo, ecological problems and countermeasures of Eucalyptus plantations in Guangxi. Acta Ecol. Sin. 2014, 34, 5142-5152. (In Chinese)

43. Rajcan, I.; Swanton, C.J. Understanding maize-weed competition: Resource competition, light quality and the whole plant. Field Crop. Res. 2001, 71, 139-150. [CrossRef]

44. Villegas, J.C.; Breshears, D.D.; Zou, C.B. Law, D.J. Ecohydrological controls of soil evaporation in deciduous drylands: How the hierarchical effects of litter, patch and vegetation mosaic cover interact with phenology and season. J. Arid Environ. 2010, 74, 595-602. [CrossRef]

45. Deal, L.M.; Hess, F.D. An analysis of the growth inhibitory characteristics of alachlor and metolachlor. Weed Sci. 1980, 28, 168-175. [CrossRef]

46. Zhang, X.; Chen, Y. Soil disturbance and cutting forces of four different sweeps for mechanical weeding. Soil Till. Res. 2017, 168, 167-175. [CrossRef]

47. Schwartz, R.C.; Baumhardt, R.L.; Evett, S.R. Tillage effects on soil water redistribution and bare soil evaporation throughout a season. Soil Till. Res. 2010, 110, 221-229. [CrossRef]

48. Yamanaka, T.; Takeda, A.; Sugita, F. A modified surface-resistance approach for representing bare-soil evaporation: Wind tunnel experiments under various atmospheric conditions. Water Resour. Res. 1997, 33, 2117-2128. [CrossRef]

49. Cook, H.F.; Valdes, G.S.; Lee, H.C. Mulch effects on rainfall interception, soil physical characteristics and temperature under Zea mays L. Soil Till. Res. 2006, 91, 227-235. [CrossRef]

50. Neave, M.; Abrahams, A.D. Vegetation influences on water yields from grassland and shrubland ecosystems in the Chihuahuan Desert. Earth Surf. Proc. Land. 2002, 27, 1011-1020. [CrossRef]

51. Sakaguchi, K.; Zeng, X. Effects of soil wetness, plant litter, and under-canopy atmospheric stability on ground evaporation in the Community Land Model (CLM3.5). J. Geophys. Res-Atmos. 2009, 114, 1-14. [CrossRef]

52. Peters, D.P.; Herrick, J.E.; Monger, H.C.; Huang, H. Soil-vegetation-climate interactions in arid landscapes: Effects of the North American monsoon on grass recruitment. J. Arid Environ. 2010, 74, 618-623. [CrossRef]

53. Gong, W.; Hu, T.X.; Wang, J.Y.; Gong, Y.B.; Ran, H. Water holding characteristics of litter layer after natural evergreen broadleaved forest artificial regeneration in southern Sichuan Province. J. Soil Water Conserv. 2006, 3, 51-55.

54. Deng, Y.S.; Duan, X.Q.; Ding, S.W.; Cai, C.F.; Chen, J.Z. Suction stress characteristics in granite red soils and their relationship with the collapsing gully in south China. Catena 2018, 171, 505-522. [CrossRef]

55. Scholl, P.; Leitner, D.; Kammerer, G.; Loiskandl, W.; Kaul, H.P.; Bodner, G. Root induced changes of effective 1D hydraulic properties in a soil column. Plant Soil 2014, 381, 193-213. [CrossRef] [PubMed]

56. Duan, X.Q.; Deng, Y.S.; Tao, Y.; He, Y.B.; Lin, L.R.; Chen, J.Z. Variation in soil saturated hydraulic conductivity along the hillslope of collapsing granite gullies. Hydrolog. Sci. J. 2018, 63, 803-817. [CrossRef]

57. Tani, M. Runoff generation processes estimated from hydrological observations on a steep forested hillslope with a thin soil layer. J. Hydrol. 1997, 200, 84-109. [CrossRef]

58. Ciais, P.; Reichstein, M.; Viovy, N.; Granier, A.; Ogée, J.; Allard, V.; Chevallier, F. Europe-wide reduction in primary productivity caused by the heat and drought in 2003. Nature 2005, 437, 529-533. [CrossRef]

59. Huxman, T.E.; Wilcox, B.P.; Breshears, D.D.; Scott, R.L.; Snyder, K.A.; Small, E.E.; Jackson, R.B. Ecohydrological implications of woody plant encroachment. Ecology 2005, 86, 308-319. [CrossRef]

60. Williams, R.A. Mitigating biodiversity concerns in Eucalyptus plantations located in South China. J. Biosci. Med. 2015, 3, 1-8. [CrossRef] 
61. Hartnett, D.C.; Potgieter, A.F.; Wilson, G.W.T. Fire effects on mycorrhizal symbiosis and root system architecture in southern African savanna grasses. Afr. J. Ecol. 2005, 42, 328-337. [CrossRef]

62. Chiatante, D.; Di Iorio, A.; Sciandra, S.; Scippa, G.S.; Mazzoleni, S. Effect of drought and fire on root development in Quercus pubescens Willd. and Fraxinus ornus L. seedlings. Environ. Exp. Bot. 2006, 56, 190-197. [CrossRef] 